\title{
CARBONISATION-ACTIVATION OF OIL PALM KERNEL SHELL TO PRODUCE ACTIVATED CARBON AND METHYLENE BLUE ADSORPTION KINETICS
}

\author{
NAHRUL HAYAWIN ZAINAL*; ASTIMAR ABDUL AZIZ*; MOHAMAD FAIZAL IBRAHIM**; JUFERI IDRIS*; \\ MOHD ALI HASSAN ${ }^{\star *}$; EZYANA KAMAL BAHRIN**; NOR FAIZAH JALANI*; NUR SULIHATIMARSYILA \\ ABDUL WAFTI* and SURAINI ABD-AZIZ**
}

\begin{abstract}
The carbonisation-activation system was developed to produce activated carbon from oil palm kernel shell (OPKS). The OPKS was carbonised at $500^{\circ} \mathrm{C}$ for $3 \mathrm{hr}$ in an electric vertical reactor followed by steaming at $700^{\circ} \mathrm{C}$ for another $3 \mathrm{hr}$ in the same reactor. The process showed significant results with a high activated carbon yield of 32\%, high fixed carbon content of $88.6 \%$ with Brunauer-Emmett-Teller (BET) surface area of $305.67 \mathrm{~m}^{2} \mathrm{~g}^{-1}$. The OPKS-activated carbon was further tested to remove methylene blue. It could adsorb up to $99.7 \%$ of methylene blue using only $0.6 \mathrm{~g}_{\text {litre }}^{-1}$ dosage of OPKS-activated carbon, for $24 \mathrm{hr}$ of treatment time. The results have been correlated in the Freundlich isotherm which was well fitted to the experimental data over the methylene blue experimental concentration range with correlation coefficients of $R^{2}=0.992$.
\end{abstract}

Keywords: oil palm kernel shell, carbonisation-activation, bioadsorbent, activated carbon.

Date received: 12 October 2017; Sent for revision: 22 October 2017; Received in final form: 18 January 2018; Accepted: 5 July 2018.

\section{INTRODUCTION}

Oil palm kernel shell (OPKS) is one of the major sources of oil palm biomass with $>100000 \mathrm{t}$ being produced by the palm oil mills every year in Malaysia and expected to increase by 2020 (National Innovation Agency of Malaysia, 2013). In general, the OPKS has a high density of $0.6 \mathrm{~g}$ $\mathrm{cm}^{-3}$ with hard and tough structure due to high composition of lignin and carbon. These criteria are very important characteristics for the production of

Malaysian Palm Oil Board, 6 Persiaran Institusi,

Bandar Baru Bangi, 43000 Kajang,

Selangor, Malaysia.

** Department of Bioprocess Technology, Faculty of Biotechnology and Biomolecular Sciences, Universiti Putra Malaysia,

43400 UPM Serdang, Selangor, Malaysia.

E-mail: suraini@upm.edu.my

* Faculty of Chemical Engineering, Universiti Teknologi MARA (UiTM) Sarawak, 94300 Kota Samarahan,

Sarawak, Malaysia. activated carbon (AC) (Hidayu and Muda, 2016). The production of AC from OPKS has been the subject of interest in recent years due to a low cost and abundance generation of OPKS in the palm oil mills. The OPKS-AC is considered to be one of the most commonly used $\mathrm{AC}$ as bioadsorbent in various applications, especially in water and wastewater treatment as it has large surface area and able to remove the target compounds from aqueous solution effectively (Nor Faizah et al., 2016; Hidayu and Muda, 2016; Ismaiel et al., 2013).

In the current practice, AC including OPKS$\mathrm{AC}$ is produced using the two-stage processes, i.e carbonisation and activation. Firstly, the feedstock material is carbonised in the absence of oxygen at temperature of $<800^{\circ} \mathrm{C}$ followed by the activation of the carbonised material at $>900^{\circ} \mathrm{C}$ using chemical and/or physical agent. These two processes are usually carried out in two separate reactors, which contribute to a high energy usage, long processing duration and high cost for materials and apparatus 
(Choi et al., 2015; Hidayu and Muda, 2016). Chemical activating agent can be carried out in a single step by combining the carbonisation and activation processes; however chemical process significantly contributes to the environmental pollution (Marrakchi et al., 2017; Singh et al., 2017). Physical activating agent using steam or $\mathrm{CO}_{2}$ could be considered as alternative since it is cleaner and easier to handle than chemical process. Physical activation process could also produce AC with high surface area when heated at high heating temperatures of $>800^{\circ} \mathrm{C}$ in a single step process ranging from $800-1200 \mathrm{~m}^{2} \mathrm{~g}^{-1}$ (Herawan et al., 2013; Sierra et al., 2017; Shoaib and Al-Swaidan, 2015; Sun and Jiang, 2010; Nur Sulihatimarsyila et al., 2017).

Therefore, this study aims to develop a carbonisation-activation system with physical activation using steam in order to produce AC from OPKS. The carbonisation-activation system is operated by conducting steam activation process after carbonisation stage without terminating the operation. The OPKS-AC was fully characterised and subsequently tested as a bioadsorbent for methylene blue removal. Isotherms for the adsorption of methylene blue by OPKS-AC were measured and fitted to three different isotherm equations to determine the best isotherm model to represent the experimental adsorption data.

\section{MATERIALS AND METHODS}

\section{Raw Materials}

Raw OPKS with particle size of 6-15 mm was obtained from the Ulu Kanchong Palm Oil Mill, Ulu Kanchong Estate, Negeri Sembilan, Malaysia. The OPKS obtained was sun dried until the moisture content reached $<10 \%$ prior to carbonisationactivation process (Nahrul Hayawin et al., 2017).

\section{Carbonisation-activation Process}

About $500 \mathrm{~g}$ of OPKS was fed into an electric vertical reactor with a length of $127 \mathrm{~cm}$ and an internal diameter of $30 \mathrm{~cm}$ (Figure 1). The carbonisation process was started by heating externally at the temperature of $500^{\circ} \mathrm{C}$ for $3 \mathrm{hr}$, controlled by a K-type thermocouple placed inside the reactor. The activation process was carried out after the $3 \mathrm{hr}$ of carbonisation process by applying steam at $700^{\circ} \mathrm{C}$, produced from a steam generator and piped into the reactor for $3 \mathrm{hr}$. The steam pressure was set at 2.50 psi. The activation temperatures were automatically recorded at an interval time of $60 \mathrm{~s}$ using a data logger. The average temperature was taken for at least three runs of carbonisation-activation process. The gaseous emitted during the process was directed via a pipe at the bottom of the reactor before being discharged through a stainless steel chimney. At the end of the experiment, the OPKS-AC was removed from the reactor, oven dried at $105^{\circ} \mathrm{C}$ and ground into powder size using a heavy duty grinder (PHILIPS, US) for subsequent analyses and uses.

\section{Characterisation of $\mathrm{AC}$}

The moisture content, volatile matter, fixed carbon, and ash content ofOPKS-AC were determined using a thermogravimetric analyser (TGA) (Mettler Toledo, TGA/SDTA 851, USA). The compositions of carbon, hydrogen, nitrogen and sulphur in the OPKS-AC were determined using a CHNS analyser (LECO, CHNS932, USA). The higher heating value (HHV) of OPKS-AC was determined by burning $0.5 \mathrm{~g}$ of sample in an adiabatic oxygen bomb calorimeter (Parr, 1341 Plain Jacket Calorimeter, USA). The Brunauer-Emmett-Teller (BET) surface area and pore structure characteristic of OPKS$A C$ were determined using nitrogen adsorption at $-196^{\circ} \mathrm{C}$ (ASAP2020 Micromeritics, New York, USA). The BET surface area $\left(S_{\mathrm{BET}}\right)$ was calculated from the isotherms using density functional theory (Lastoskie et al., 1993), while total pore volumes $\left(\mathrm{V}_{\text {TOтAL }}\right)$ were estimated from the liquid volumes of $\mathrm{N}_{2}$ at a high relative pressure $\left(P / P_{O}=0.99\right)$. The micropore volume $\left(\mathrm{V}_{\text {MICRO }}\right)$ and micropore specific surface area $\left(\mathrm{S}_{\text {MICRO }}\right)$ were determined based on the $\mathrm{t}$-plot method (Rouquero et al., 1999; Barrett and Halenda, 1951).

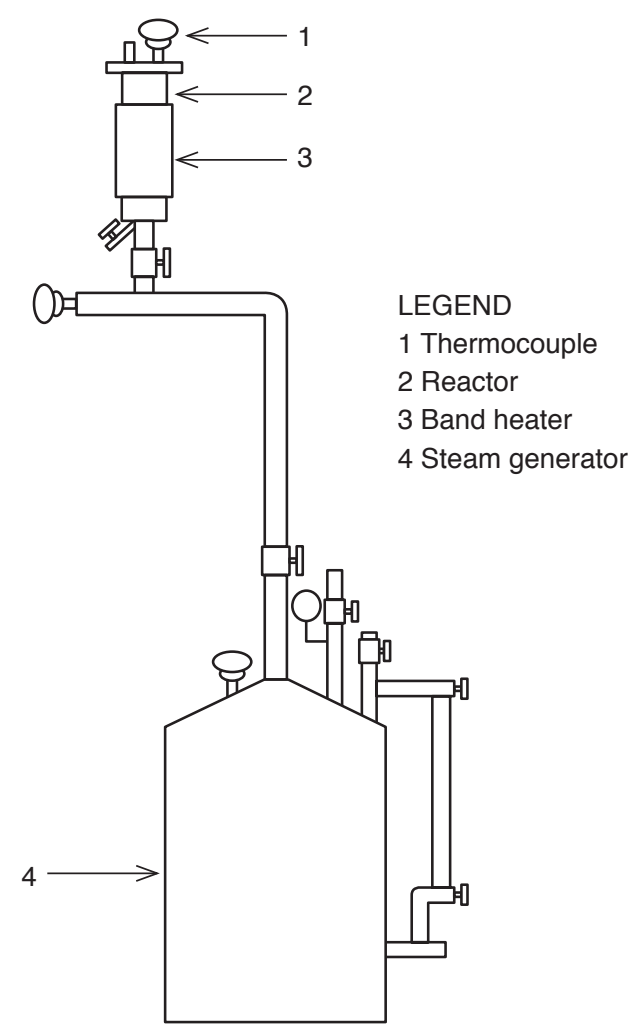

Figure 1. The electric vertical reactor used for the production of activated carbon from oil palm kernel shell (OPKS). 


\section{Adsorption of Methylene Blue}

Methylene blue was purchased from SigmaAldrich with colour content $\geq 82 \%$ and initial $\mathrm{pH}$ of 7. The adsorption of methylene blue by OPKS-AC was conducted using $0.1 \mathrm{~g}$ of OPKS-AC into $25 \mathrm{ml}$ of $500-2000 \mathrm{mg}$ litre $^{-1}$ of methylene blue prepared in $100 \mathrm{ml}$ of Erlenmeyer flasks. The process was conducted for $24 \mathrm{hr}$ at room temperature of $25^{\circ} \mathrm{C}$. Then, the samples were separated by filtration using a vacuum pump. The methylene blue concentrations were determined using a UV-Vis spectrophotometer at a wavelength of $665 \mathrm{~nm}$ with the $\mathrm{R}^{2}=0.999$. The amount of methylene blue adsorbed onto activated carbon $\left(\mathrm{q}_{\mathrm{e}}\right)$ and the percentage of methylene blue removal ( $\mathrm{R} \%$ ) were calculated using Equations (1) and (2).

$$
\begin{array}{ll}
\mathrm{q}_{\mathrm{e}}=\frac{V\left(\mathrm{C}_{0}-\mathrm{C}_{\mathrm{e}}\right)}{\mathrm{W}} & \text { Equation (1) } \\
\mathrm{R}(\%)=\frac{V\left(\mathrm{C}_{0}-\mathrm{C}_{\mathrm{e}}\right)}{\mathrm{C}_{0}} \times 100 & \text { Equation (2) }
\end{array}
$$

where $\mathrm{C}_{0}$ and $\mathrm{C}_{\mathrm{e}}$ are the initial and equilibrium concentrations of methylene blue in mg litre ${ }^{-1}$, respectively, $V$ is the volume of the solution (litre), and $W$ is the mass of adsorbent $(\mathrm{g})$.

In order to evaluate the effect of adsorbent dosage, four batch experiments were carried out by adding different amounts of OPKS-AC (0.20-0.80 g) into $1000 \mathrm{ml}$ of $500 \mathrm{mg} \mathrm{ml}$ methylene blue solution.

\section{Sorption Isotherm Models}

The sorption equilibrium data of methylene blue onto OPKS-AC was analysed following the Freundlich, Langmuir and Temkin isotherm models. The linear form of Freundlich's isotherm model is given by Equation (3):

$$
\log q_{e}=\log q_{e}+\frac{1}{n} \log C_{e} \quad \text { Equation (3) }
$$

where $\mathrm{k}_{\mathrm{f}}\left[\left(\mathrm{mg} \mathrm{g}^{-1}\right)\left(\text { litre } \mathrm{g}^{-1}\right)^{1 / \mathrm{n}}\right]$ and $n$ are the Freundlich constants that are related to the adsorption capacity and intensity, respectively. The Freundlich constants $\mathrm{k}_{\mathrm{f}}$ and $n$ can be calculated from the slope and intercept of the linear plot, with $\log \mathrm{q}_{\mathrm{e}}$ versus $\log C_{e}$.

The linear form of Langmuir's isotherm model is given by Equation (4).

$$
\frac{C_{e}}{q_{e}}=\frac{1}{b q_{m}}+\frac{C_{e}}{q_{m}}
$$

Equation (4)

where $b$ (litre $\mathrm{mg}^{-1}$ ) is the Langmuir constant related to the rate of adsorption. The essential characteristics of the Langmuir isotherm can also be expressed in terms of a dimensionless constant separation factor or equilibrium parameter, $R_{L}$ which is defined in Equation (5).

$$
\mathrm{R}_{\mathrm{L}}=\frac{1}{\mathrm{bC}_{\mathrm{e}}}
$$

where $b$ is the Langmuir constant and $\mathrm{C}_{0}$ is the initial concentration of $\mathrm{MB}$. The value of $\mathrm{R}_{\mathrm{L}}$ indicates the type of the isotherm to be either unfavourable $\left(R_{L}>1\right)$, linear $\left(R_{L}=1\right)$, favourable $\left(0<R_{L}<1\right)$ or irreversible $(\mathrm{RL}=0)$.

The linear form of Temkin isotherm can be expressed in Equation (6).

$$
\mathrm{q}_{\mathrm{e}}=\mathrm{B} \log \mathrm{kt}+\mathrm{B} \log \mathrm{C}_{\mathrm{e}} \quad \text { Equation (6) }
$$

where $B=\frac{R T}{b}$ represents heat of adsorption, $T$ is the absolute temperature in Kelvin and $R$ is the universal gas constant, $\frac{1}{b}$ indicates the adsorption potential of the adsorbent while $\mathrm{k}_{\mathrm{t}}$ (litre $\mathrm{mg}^{-1}$ ) is the equilibrium binding constant corresponding to the maximum binding energy. The plot of qe versus log $\mathrm{C}_{\mathrm{e}}$ enables the determination of isotherm constants $\mathrm{k}_{\mathrm{t}}$ and $B$.

\section{RESULTS AND DISCUSSION}

\section{Temperature Profile during Carbonisation- activation Process}

Figure 2 shows the temperature profile during carbonisation-activation process of OPKS, and it indicates that carbonisation process took place at minutes 90-270 and while activation process at minutes 300-540. The temperature was taken in average of at least three runs of carbonisationactivation process. The temperature in the electric vertical reactor gradually increased from $0^{\circ} \mathrm{C}$ to $500^{\circ} \mathrm{C}$ (heating rate $200^{\circ} \mathrm{C} / 30 \mathrm{~min}$ ) when the heat was introduced within the first $90 \mathrm{~min}$ (Figure 2). During carbonisation process at temperature between $300^{\circ} \mathrm{C}-500^{\circ} \mathrm{C}$, OPKS released more volatiles compounds as cellulose and lignin content is decomposed at temperature of $>400^{\circ} \mathrm{C}$ (Choi et al., 2015), therefore, the carbon content was increased. For activation process, the temperature was raised from $500^{\circ} \mathrm{C}$ to $700^{\circ} \mathrm{C}$ within $90 \mathrm{~min}$ and remained constant until minute 540 , before the process was stopped by turning off the steam generation. During this process, more pores were developed and the existing pores were enlarged. The tar that has been filled into the pores during carbonisation process was also removed during the activation process, which had improved the total number of pores and subsequently increased the surface area of AC produced (Abdullah et al., 2011). The feasibility study gave significant results where overall time taken to produce OPKS-AC was only $6 \mathrm{hr}$ with the 


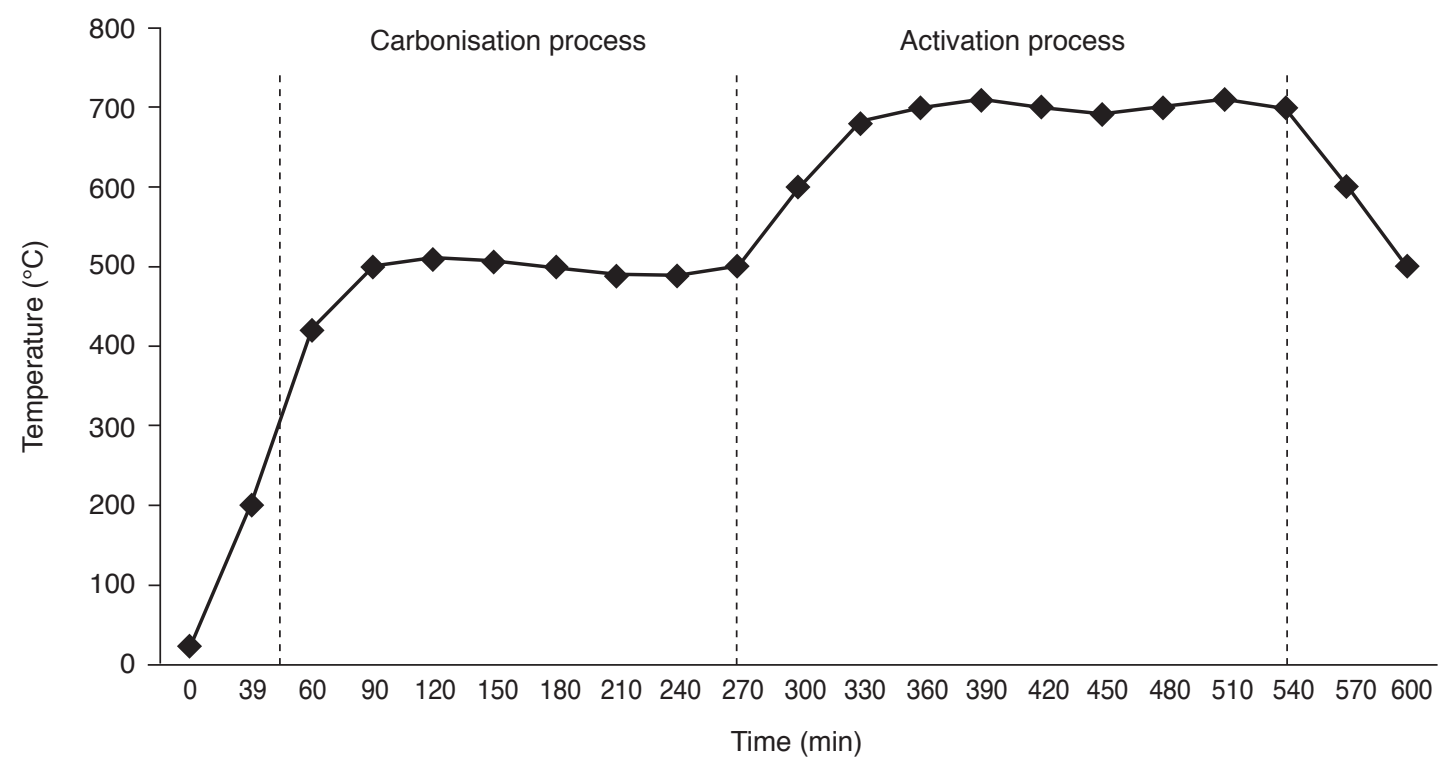

Figure 2. The temperature profile during carbonisation-activation of oil palm kernel shell (OPKS) using electric vertical reactor.

lowest maximum activation temperature at $700^{\circ} \mathrm{C}$ as compared to the other studies (Sawant et al., 2017; Selvaraju and Bakar, 2017).

\section{Characteristics of OPKS-AC}

Proximate and ultimate analysis. An earlier analysis shows that the volatile matter, ash and fixed carbon contents of raw OPKS are $53.40 \%$, $0.87 \%$ and $18.84 \%$, respectively (Nahrul Hayawin et al., 2017). After the carbonisation-activation process of OPKS, the OPKS-AC had the highest fixed carbon content of $88.6 \%$ and the lowest volatile matter of $3.5 \%$ as compared to other studies (Table 1). This phenomenon is due to the rapid release of volatile matter content at high temperature during steam activation process (Arami-Niya et al., 2012). The OPKS-AC also has the lowest ash content of $2.6 \%$, which is ideal for producing $\mathrm{AC}$ with highly porous structure (Abdullah et al., 2011). The results of the proximate and ultimate analyses show that the OPKS-AC produced through the carbonisationactivation system is comparable to AC reported in other studies as shown in Table 1.

Pore characteristics of OPKS-AC. Table 2 shows that the OPKS-AC produced through carbonisationactivation system has the BET surface area, micropore surface area, micropore volume and total volume lower than commercial AC purchased from Sigma. However, the OPKS-AC produced in this study still has the characteristics in the range of standard limit for commercial AC set by gold processing industry, Norit-CAC-Au (Hidayu and Muda, 2016; Ismaiel et al., 2013; Jia and Lua, 2008). According to Buah and Kuma (2016), pore volume, surface area and pore size distribution are important quantitative characterisation of the $\mathrm{AC}$

TABLE 1. PROXIMATE AND ULTIMATE ANALYSES OF OIL PALM KERNEL

SHELL-ACTIVATED CARBON (OPKS-AC)

\begin{tabular}{|c|c|c|c|}
\hline Analysis & $\begin{array}{l}\text { OPKS-AC } \\
\text { (This study) }\end{array}$ & Other AC & References \\
\hline \multicolumn{4}{|l|}{ Proximate $(\%)$} \\
\hline Moisture content & $4.3 \pm 0.3$ & $1.9-4.6$ & Arami-Niya et al. (2010) \\
\hline Ash content & $2.6 \pm 0.2$ & $2.6-10.6$ & Choi et al. (2015); Arami-Niya et al. (2010) \\
\hline Volatile matter & $3.5 \pm 0.9$ & $10.2-45.9$ & Arami-Niya et al. (2010) \\
\hline Fixed carbon & $88.6 \pm 2.4$ & $44.5-83.0$ & Arami-Niya et al. (2010) \\
\hline \multicolumn{4}{|l|}{ Ultimate $(\%)$} \\
\hline $\mathrm{C}$ & $78.5 \pm 4.6$ & $59.6-85.0$ & $\begin{array}{l}\text { Hidayu and Muda (2016); Rugayah et al. } \\
\text { (2014); Arami-Niya et al. (2010) }\end{array}$ \\
\hline $\mathrm{H}$ & $2.17 \pm 0.0$ & $0.5-4.1$ & $\begin{array}{l}\text { Hidayu and Muda (2016); Rugayah et al. } \\
\text { (2014); Arami-Niya et al. (2010) }\end{array}$ \\
\hline $\mathrm{N}$ & $0.41 \pm 0.0$ & $0.02-2.9$ & Hidayu and Muda (2016); Arami-Niya et al. (2010) \\
\hline
\end{tabular}


porosity. It should also be noted that this OPKS-AC was produced within a short processing duration of $3 \mathrm{hr}$, at a relatively low activation temperature of $700^{\circ} \mathrm{C}$ and using carbonisation-activation system without involvement of chemical agent. Besides, this process also produced high yield of OPKS-AC $(32 \%)$ which is higher than those reported in the literature as shown in Table 3. Higher AC yields correspond to steam activation of biomass materials, while chemical activation usually produces lower AC yield. Increasing the activation temperature will increase the surface area by enlarging the existing pores as well as creating new pores. However, too high an activation temperature will decrease the AC yield because it will enhance the evaporation of volatile compounds (Shoaib and Al-Swaidan, 2015). In addition, the resulted surface area for
OPKS-AC is shown to be related to the nature of biomass materials itself. Different biomass materials will produce AC with different surface area and pore development. The performance of OPKS-AC produced in this study was evaluated by conducting adsorption test on methylene blue.

\section{Adsorption of Methylene Blue}

Effect of adsorbent dosage. The adsorption test of methylene blue by OPKS-AC was conducted using 0.2-0.8 $\mathrm{g} \mathrm{litre}^{-1}$ of OPKS-AC dosage mixed with $25 \mathrm{ml}$ of $500 \mathrm{mg}^{\text {litre }}{ }^{-1}$ initial concentration (Co) of methylene blue at $\mathrm{pH} 7$ for $24 \mathrm{hr}$ contact time. The results of this test are shown in Figure 3. It is clearly observed that the percentage removal of methylene blue was increased by increasing the OPKS-AC

TABLE 2. PORE CHARACTERISTICS OF OIL PALM KERNEL SHELL-ACTIVATED CARBON (OPKS-AC) IN COMPARISON WITH COMMERCIAL AC AND COMMERCIAL AC STANDARD LIMIT

\begin{tabular}{lcccc}
\hline Sample & $\begin{array}{c}\mathbf{S}_{\text {BET }} \\
\left(\mathbf{m}^{2} \mathbf{g}^{-1}\right)\end{array}$ & $\begin{array}{c}\mathbf{S}_{\text {MICRO }} \\
\left(\mathbf{m}^{2} \mathbf{g}^{-1}\right)\end{array}$ & $\begin{array}{c}\mathbf{V}_{\text {MICRO }} \\
\left(\mathbf{c m}^{3} \mathbf{g}^{-1}\right)\end{array}$ & $\begin{array}{c}\mathbf{V}_{\text {TOTAL }} \\
\left(\mathbf{c m}^{3} \mathbf{g}^{-1}\right)\end{array}$ \\
\hline $\begin{array}{l}\text { OPKS-AC } \\
\begin{array}{l}\text { This study) } \\
\text { aCommercial AC }\end{array}\end{array}$ & 112.89 & 0.09 & 0.14 \\
$\begin{array}{l}\text { Standard limit for } \\
\text { commercial AC }\end{array}$ & 541.57 & 223.60 & 0.12 & 0.25 \\
\hline
\end{tabular}

Note: ${ }^{2}$ Commercial AC was purchased from Sigma Aldrich in powder form.

TABLE 3. PRODUCTION OF ACTIVATED CARBON (AC) FROM VARIOUS TYPES OF BIOMASS

\begin{tabular}{lccccc}
\hline Biomass & $\begin{array}{c}\text { Activating } \\
\text { agent }\end{array}$ & $\begin{array}{c}\text { Activation } \\
\text { temperature }\left({ }^{\circ} \mathbf{C}\right)\end{array}$ & $\begin{array}{c}\text { Surface area } \\
\left(\mathbf{m}^{\mathbf{2}} \mathbf{~ g}^{-\mathbf{1}} \mathbf{)}\right.\end{array}$ & $\begin{array}{c}\text { Yield } \\
\mathbf{( \% )}\end{array}$ & References \\
\hline Oil palm kernel shell & Steam & 800 & 584 & 22.0 & Hidayu and Muda (2016) \\
Coconut shell & Steam & 800 & 1011 & 24.0 & Hidayu and Muda (2016) \\
Olive stones & Steam & 750 & 807 & 25.0 & Ghouma et al. (2015) \\
Date palm tree & $\mathrm{CO}_{2}$ & 576 & 385 & 28.4 & Shoaib and Al-Swaidan (2015) \\
Yellow mombin fruit stones & $\mathrm{KOH}$ & 500 & 222 & 12.5 & Brito et al. (2017) \\
Rice husk & $\mathrm{KOH}$ & 850 & $1499-2696$ & $16.5-17.4$ & Muniandy et al. (2014 \\
Oil palm kernel shell & Steam & 700 & 306 & 31.0 & This study \\
\hline
\end{tabular}

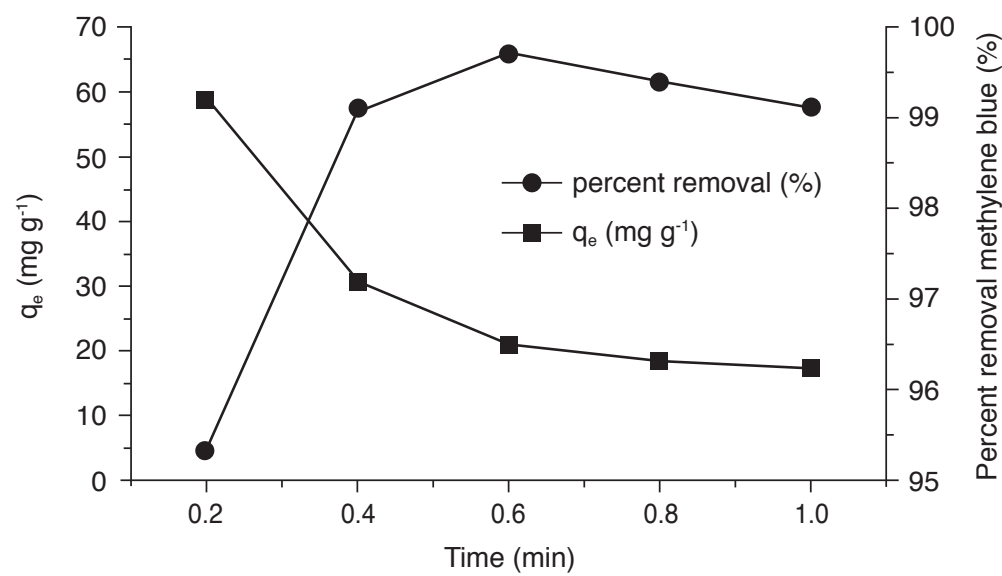

Figure 3. Effect of oil palm kernel shell-activated carbon (OPKS-AC) dosage on the removal of methylene blue and adsorption capacity. 
dosage. The percentage of methylene blue removal achieved up to $99.7 \%$ when OPKS-AC dosage was at $0.6 \mathrm{~g} \mathrm{litre}^{-1}$ due to the number of available adsorption site was increased when the adsorbent dosage has been increased until it reached the stationary adsorption state (Garg et al., 2003). However, increasing the adsorbent dosage can contribute to the decrease of the adsorption capacity due to the adsorption reaction remains unsaturated (Sharma and Foster, 1993). The adsorption process and adsorption capacity are dependence on the specific surface area of the materials. The adsorption process and capacity will increase when the adsorbents have wide surface area, small particle size and porous structure (Diaz et al., 2013). The percentage of methylene blue removal was reduced to $99.3 \%$ when OPKS-AC dosage of $0.8 \mathrm{~g}$ litre $^{-1}$ was used.

Adsorption isotherms. The OPKS-AC produced was tested by adsorption isotherm in order to identify the best fitting isotherm for the adsorption mechanism. The adsorption isotherm studies were conducted by changing $\mathrm{C}_{\mathrm{o}}$ of methylene blue with a fixed OPKS$\mathrm{AC}$ dosage at $0.6 \mathrm{~g} \mathrm{litre}^{-1}$. The equilibrium data were analysed using Langmuir, Freundlich and Temkin equilibrium models and shown graphically in Figure 4. All of the plots show a straight line indicating that the adsorption of methylene blue is suitable with all the isotherm equilibrium models. However, the coefficients indicate that the Freundlich isotherm fitted more precisely $\left(R^{2}=0.992\right)$ than the Temkin isotherm $\left(R^{2}=0.867\right)$ and the Langmuir isotherm $\left(R^{2}=0.826\right)$ as shown in Table 4. Freundlich model has the maximum adsorption value of $10.93 \mathrm{mg}$ $\mathrm{g}^{-1}$ as well as the high $R^{2}$ value for methylene blue adsorption on the OPKS-AC thus supporting multilayer adsorption and physisorption mechanism. This adsorption isotherm also can be used on a heterogeneous surface energy system if the binding sites are not similar (Freundlich, 1906). Moreover, the value of $n>1$ represents favourable adsorption condition (Namasivayam et al., 1994). This study shows that the OPKS-AC produced through carbonisation-activation system has the capacity to be used as adsorbent after being tested on methylene blue.

\section{CONCLUSION}

The carbonisation-activation system is capable to produce OPKS-AC with high fixed carbon content of $88.6 \%$, high yield of $32.0 \%$, and at a low activation temperature of $700^{\circ} \mathrm{C}$ using steam. The OPKS-AC also contains BET surface area of $305.67 \mathrm{~m}^{2} \mathrm{~g}^{-1}$, which is in the range of commercial AC standard limit. The OPKS-AC produced also has been tested on methylene blue adsorption test, which was fitted to all the isotherm equilibrium models with Freundlich model showing the best correlation
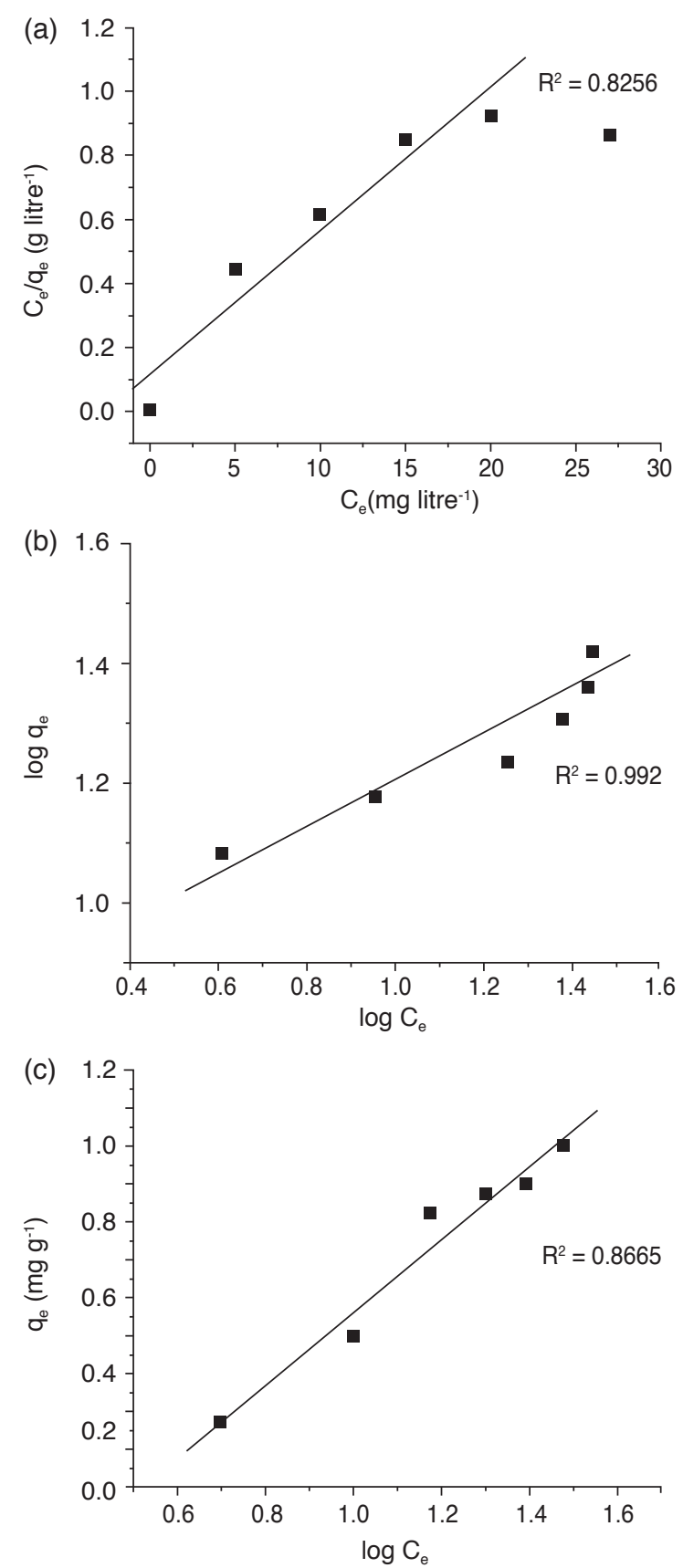

Figure 4. Langmuir (a), Freundlich (b) and Temkin (c) adsorption isotherms of methylene blue by oil palm kernel shell-activated carbon (OPKS-AC).

TABLE 4. EQUILIBRIUM MODEL PARAMETERS FOR ADSORPTION OF METHYLENE BLUE BY OIL PALM KERNEL SHELL-ACTIVATED CARBON (OPKS-AC)

\begin{tabular}{lll}
\hline Equilibrium model & Parameter & Value \\
\hline Langmuir isotherm & $q_{m}\left(\mathrm{mg} \mathrm{g}^{-1}\right)$ & 9.255 \\
& $b\left(\right.$ litre mg $\left.^{-1}\right)$ & 54.347 \\
& $R^{2}$ & 0.826 \\
Freundlich isotherm & $k_{f}\left(\mathrm{mg} \mathrm{g}^{-1}\right)\left(\text { litre g }^{-1}\right)^{1 / n}$ & 10.927 \\
& $n$ & 15.873 \\
Temkin isotherm & $R^{2}$ & 0.992 \\
& $k_{t}\left(\right.$ litre mg- $\left.^{-1}\right)$ & 7390.95 \\
& $b\left(\mathrm{~J} \mathrm{~mol}^{-1}\right)$ & 887.352 \\
& $B\left(\right.$ litre g $\left.^{-1}\right)$ & 2.792 \\
& $R^{2}$ & 0.867 \\
\hline
\end{tabular}


coefficient of $R^{2}=0.992$. This study suggests that the production of OPKS-AC using carbonisationactivation system could give a great positive impact towards the environment and economic viability especially in the palm oil industry.

\section{ACKNOWLEDGEMENT}

The authors are thankful to MPOB and Universiti Putra Malaysia (UPM) for the financial support that was provided to conduct this study.

\section{REFERENCES}

ABDULLAH, M O; TAN, I A W and LIM, L S (2011). Automobile adsorption air-conditioning system using oil palm biomass-based activated carbon: A review. Renewable and Sustainable Energy Reviews, 15: 2061-2072.

ARAMI-NIYA, A; MOHD, W; WAN, A and MJALLI, F (2010). Using granular activated carbon prepared from oil palm shell by $\mathrm{ZnCl} 2$ and physical activation for methane adsorption. J. Analytical and Applied Pyrolysis, 89: 197-203.

ARAMI-NIYA, A; WAN DAUD, W M A; MJALLI, F; ABNISA, F and SHAFEEYAN, MS (2012). Production of microporous palm shell based activated carbon for methane adsorption: Modeling and optimization using response surface methodology. Chemical Engineering Research and Design, 90: 776-784.

BARRETT, L G J E P and HALENDA, P P (1951). The determination of pore volume and area distributions in porous substances, I. Computations from nitrogen isotherms, J. Amer. Oil Chem. Soc. Vol. 73: 373-380.

BUAH, W K and KUMA, J S Y (2016). Design of a novel gas fired static bed pyrolysis-gasification reactor for the production of activated carbons. Process Safety and Environmental Protection, 102: 353360.

BRITO, M; VELOSO, C; BONOMO, R; FONTAN, R; SANTOS, L and MONTEIRO, K (2017). Activated carbons preparation from yellow mombin fruit stones for lipase immobilization. Fuel Processing Technology, 156: 421-428.

CHOI, G G; OH, S J; LEE, S J and KIM, J S (2015). Production of bio-based phenolic resin and activated carbon from bio-oil and biochar derived from fast pyrolysis of palm kernel shells. Bioresource Technology, 178: 99-107.

DIAZ, T; NEVSKAIA, D and JEREZ, A (2013). Study of chemical activation process of lignocellulosic material with $\mathrm{KOH}$ by XPS and XRD. Microporous Mesoporous Materials, 60: 173-181.

FREUNDLICH, H M F (1906). Over the adsorption in solution. The J. Phys. Chem., 57: 385-471.

GARG, V; GUPTA, R; BALA YADAV, A and KUMAR, $R$ (2003). Dye removal from aqueous solutions by adsorption on treated sawdust. Bioresource Technology, 89: 121-124.

GHOUMA, I; JEGUIRIM, M; DORGE, S; LIMOUSY, L; GHIMBEU, C M and OUEDERNI, A (2015). Activated carbon prepared by physical activation of olive stones for the removal of $\mathrm{NO}_{2}$ at ambient temperature. Comptes Rendus Chimie, 18(1): 63-74.

HERAWAN, S G; HADI, M S; AYOB, M R and PUTRA, A (2013). Characterization of activated carbons from oil-palm shell by $\mathrm{CO}_{2}$ activation with no holding carbonization temperature. Science World J. Vol. 2013: 1-6.

HIDAYU, A R and MUDA, N (2016). Preparation and characterization of impregnated activated carbon from palm kernel shell and coconut shell for $\mathrm{CO}_{2}$ capture. $4^{\text {th }}$ International Conference on Process Engineering and Advanced Materials. Procedia Engineering, 148: 106-113.

ISMAIEL, A A; AROUA, M K and YUSOFF, R (2013). Palm shell activated carbon impreganated with task-specific ionic-liquids as a novel adsorbent for the removal of mercury from contaminated water. Chemical Engineering J., 225: 306-314.

JIA, Q and LUA, A C (2008). Effects of pyrolysis conditions on the physical characteristics of oilpalm-shell activated carbon used in aqueous phase phenol adsorption. J. Analytical and Applied Pyrolysis, 83: $175-179$

LASTOSKIE, C; GUBBINS, K E and QUIRKE, N J (1993). Pore size distribution analysis of microporous carbons: density functional theory approach. The J. Physical Chemistry, 97: 4786-4796.

MARRAKCHI, F; AHMED, M J; KHANDAY, W A; ASIF, M and HAMEED, B H (2017). Mesoporousactivated carbon prepared from chitosan flakes via single-step sodium hydroxide activation for the adsorption of methylene blue. International J. Biological Macromolecules, 98: 233-239.

MUNIANDY, L; ADAM, F; MOHAMED, A and ENG-POH, N (2014). The synthesis and characterization of high purity mixed microporous / mesoporous activated carbon from rice husk using chemical activation with $\mathrm{NaOH}$ and $\mathrm{KOH}$. Microporous Mesoporous Materials, 197: 316-323. 
NAHRUL HAYAWIN, Z; ASTIMAR, A A; IDRIS, J; ROPANDI, M; HASSAN, M A; BAHRIN, E K and ABD-AZIZ, S (2017). Microwave-assisted pre-carbonisation of palm kernel shell produced charcoal with high heating value and low gaseous emission. J. Cleaner Production, 142: 2945-2949.

NAMASIVAYAM, C; JEYAKUMAR, $\mathrm{R}$ and YAMUNA, R (1994). Dye removal from wastewater by adsorption on 'waste' Fe (III)/ Cr (III) hydroxide. Waste Management, 14: 643-648.

NATIONAL INNOVATION AGENCY OF MALAYSIA (2013). National Biomass Strategy 2020: New Wealth Creation for Malaysia's Palm Oil Industry. version 2.0.

NIZAMUDDIN, S; MUBARAK, N; TIRIPATHI, $\mathrm{M}$; JAYAKUMAR, $\mathrm{N}$; SAHU, J and GANESAN, $P$ (2016). Chemical, dielectric and structural characterization of optimized hydrochar produced from hydrothermal carbonization of palm shell. Fuel, 163: 88-97.

NOR FAIZAH, J; ASTIMAR, A A; NOORSHAMSIANA, A A; HASSAN, W $\mathrm{H}$ and NAHRUL HAYAWIN, Z (2016). Application of palm kernel shell activated carbon for the removal of pollutant and colour in palm oil mill effluent. $J$. Earth, Environment and Health Sciences, 2: 15-20.

NUR SULIHATIMARSYILA, A W; LAU, H L N; LOH, S K; ASTIMAR, A A; ZULKIFLI, A R and CHOO, Y M (2017). Activated carbon from oil palm biomass as potential adsorbent for palm oil mill effluent treatment. J. Oil Palm Res. Vol. 29 (2): 278-290.

ROUQUEROL, F; ROUQUEROL, J and SING, K (1999). Chapter 6 - Assessment of surface area. Adsorption by Powders and Porous Solids. Academic Press, London. p. 165-189.

RUGAYAH, A; ASTIMAR, A and NORZITA, N (2014). Preparation and characterisation of activated carbon from palm kernel shell by physical activation with steam. J. Oil Palm Res. Vol. 26: 251-264.

SAWANT, S Y; MUNUSAMY, K; SOMANI R S; JOHN, M; NEWALKAR, B L and BAJAJ, H C (2017). Precursor suitability and pilot scale production of super activated carbon for greenhouse gas adsorption and fuel gas storage. Chemical Engineering J., 315: 415-425.

SELVARAJU, G and BAKAR, N K A (2017). Production of a new industrially viable greenactivated carbon from Artocarpus integer fruit processing waste and evaluation of it chemical, morphological and adsorption properties. J. Cleaner Production, 141: 989-999.

SHARMA, D C and FORSTER, C F (1993). Removal of hexavalent chromium using sphagnum moss peat. Water Resources, 27: 1201-1208.

SHOAIB, M and AL-SWAIDAN, H M (2015) Optimization and characterization of sliced activated carbon prepared from date palm tree fronds by physical activation. Biomass and Bioenergy, 73: 124-134.

SIERRA, I; IRIARTE-VELASCO, U; GAMERO, M and AGUAYO, A T (2017). Upgrading of sewage sludge by demineralization and physical activation with $\mathrm{CO}_{2}$ : Application for methylene blue and phenol removal. Microporous and Mesoporous Materials, 250: 88-99.

SINGH, G; KIM, IY; LAKHI, K S; SRIVASTAVA, P; NAIDU, R and VINU, A (2017). Single step synthesis of activated bio-carbons with a high surface area and their excellent $\mathrm{CO}_{2}$ adsorption capacity. Carbon, 116: 448-455.

SUN, K and JIANG, J C (2010). Preparation and characterization of activated carbon from rubberseed shell by physical activation with steam. Biomass and Bioenergy, 34 (4): 539-544. 